\title{
Psalm 136: 'n Liturgie as herinnering en herbelewenis van God se krag in die skepping en in die geskiedenis
}

\author{
Dirk J Human \\ Departement Ou-Testamentiese Wetenskap \\ Universiteit van Pretoria
}

\begin{abstract}
Psalm 136: A liturgy as remembrance and reenactment of God's power in creation and history

Psalm 136 is a litany in which elements of the Israelite thanksgiving hymn give expression to the celebration of the character and deeds of Yahweh. In the cult of ancient Israel this poem has probably functioned as liturgy to express God's power over and against all other powers in creation and in history. In a polemic manner it serves as a remembrance and re-enactment of the incomparable God's power as the "God of gods" and the "Lord of lords". The psalm has a unique composition and structure in the Psalter. It also reflects a variety of poetic features that serve as literary vehicles to enhance the psalm's theological content. For the cultic Sitz im Leben a variety of possibilities exists where Psalm 136 could have functioned. Although it is difficult to exactly date the text, there are indications in the psalm that it could be dated back to the end of the fifth or to the beginning of the fourth century $B C E$.
\end{abstract}

\section{INLEIDING}

Volgens die Talmoed en ander Rabbynse geskrifte is die skouspelagtige Psalm 136 met sy merkwaardige inhoud in die laat Joodse tradisie bekend as die Hallel ha-Gadôl, die Groot Hallel (Oesterley 1939:542). ${ }^{1}$ Vanweë die inleidende ( vv 1-3) en afsluitende ( $v 26$ ) imperatief om Jahwe te prys en te dank, vorm Psalm 136 deel van die gallery van die vyf "Hôdū-psalms" (Pss

\footnotetext{
${ }^{1}$ Volgens die Talmoed en Midrasj is daar drie moontlikhede vir die omvang van die Groot Hallel: 1) Ps 136 alleen; 2) Pss 135-136, weens hulle prominente literêre en teologiese interverhouding, kyk ook König (1927:451); en 3) Pss 120-136.
} 
105-107; 118; 136), om sodoende die waardering vir die karakter en dade van Jahwe, die God van Israel, uit te beeld.

Tussen ander himniese versamelings, soos die Egiptiese Hallel (Pss 113-118) en die Slothallel (Pss 146-150), oortref hierdie gedig die aantal lofprysings of uitroepe van danksegging van ander versamelings deur die herhaling van sy luidende en monotoniese refrein: "want sy troue liefde duur vir altyd", 'n loftuiting wat ses-en-twintig keer hoorbaar word in die stem van dankbare Jahwe-gelowiges. ${ }^{2}$

Met 'n hoofsaaklik himniese karakter, binne 'n litanie-gevormde struktuur, neig Psalm 136 om nabootsings van soortgelyke lofliedere in Qumran ${ }^{3}$ en in deutero-kanoniese tekste, soos die lied van die drie jong mans in die vuuroond (Dan 3:52-90) of die pryslitanie in die gebed van Ben Sirag (Ekkl 51.12) te reflekteer. Ander buite-Bybelse parallelle met soortgelyke refreine is sigbaar in 'n lied toegewy aan El (Obermann 1936:21-44) of lofliedere gesing vir die Babiloniese god Marduk, die god Ninurta of vir die Egiptiese Farao Sesostris III (Van der Ploeg 1974:417). Hierdie litanieë van lofprysing, versoek en klag, bevat konstante en herhalende refreine wat in wederkerige interaksie tussen 'n voorsanger en 'n groep, of tussen verskillende groepe in die kultus geuiter word. Soos Psalm 136 het hulle waarskynlik deel gevorm van liturgiese rituele gedurende godsdienstige aanbidding.

In Psalm 136 word die opnoem van Jahwe se buitengewone kwaliteite en sy prysenswaardige dade in die eerste helfte van elke vers afgewissel met 'n antifoniese refrein in die tweede helfde van die vers - 'n refrein wat aan die psalm 'n unieke komposisionele en artistieke karakter verleen. Dit blyk die mees uitstaande en dominante stilistiese kenmerk van die teks te wees, en ten spyte van ooreenkomste met die patroon van die vorige psalm, bestaan daar geen parallelle vir Psalm 136 se struktuur in die Psalmbundel nie.

Wat mag lyk na 'n doellose herhaling van 'n antifoniese refrein, bind uiteindelik die verskeie uitbeeldings van Jahwe saam tot 'n koherente geheel. Die frase "want sy troue liefde duur vir altyd", in kombinasie met 'n voorafgaande beskrywing, funksioneer soos 'n verligte, roterende diamant, wat algaande die veelvuldige beeld van Jahwe se dade en eienskappe vanuit verskillende hoeke uitstraal. So bou elke herhaling van die refrein op tot 'n reeks ondervindinge wat tot die durende karakter van Jahwe se "troue liefde" bydra.

\footnotetext{
${ }^{2}$ In Ps 118:1-4 kom hierdie frase slegs vier maal voor.

${ }^{3}$ Kyk die refrein na elke vers in Ps 145 (IIQPs $\left.{ }^{\mathrm{a}}\right)$.
} 


\section{TEKS EN STRUKTUUR}

\subsection{Inleiding}

Die Hebreeuse teks van Psalm 136 is goed bewaar en oorgelewer. Met die uitsondering van verse 4, 9, 12 en 15 is 'n konstante metriese patroon sigbaar. Slegs verse 9 en 15 kan weens metriese redes aan tekskritiese heroorweging onderwerp word.

Vanweë die ongebalanseerde metrum van vers 9 in vergelyking met die res van die gedig word voorgestel dat וכוכבים (en sterre) weggelaat word. Verder behoort die meervoudsvorm לממשלות (vir oorheersing/om te heers) na die enkelvoudsvorm לממשלת verander te word. 'n Verdere argument vir hierdie tekstuele aanpassing is dat "die sterre" 'n latere toevoeging tot die teks mag wees omdat die sterre nie as mederegeerders van die nag in Genesis 1:16 aangedui word, waarop Psalm 136:9 waarskynlik sinspeel nie. Die sterre word in die Genesis teks (1:16) slegs saam met die maan genoem, wat alleen die rol van heerser oor die nag speel. Op dieselfde manier is daar menige voorstelle dat die naamwoord וחילו (en sy leerskare) in vers 15 uitgelaat behoort te word op grond van die metrum. Aangesien dit egter onmoontlik is vir die leser om die bedoeling van die skrywer in sy toepassing van metriese patrone te onderskei, weerhou ek my van enige van die bogenoemde tekskritiese voorstelle. Die Masoretiese teks is duidelik sonder enige tekskritiese verandering en hoef vir daardie rede nie aangepas te word nie.

\subsection{Vertaling}

Die volgende vertaling verskaf 'n moontlike verstaan van die teks, en stel terselfdertyd ' $n$ moontlike struktuur in die diskoers voor:

1 Bring dank aan die HERE, want Hy is goed,

2 Bring dank aan die God van die gode,

3 Bring dank aan die Heer van die here,

4 aan Hom wat alleen groot wonders doen,

5 wat deur sy insig die hemele gemaak het,

6 wat die aarde oor die waters uitgesprei het,

7 wat die groot ligte gemaak het, 8 die son om te heers oor die dag,

9 die maan en sterre om te heers oor die nag;

10 aan Hom wat die eersgeborene van Egipte verslaan het, want sy troue liefde duur vir altyd. want sy troue liefde duur vir altyd. want sy troue liefde duur vir altyd

want sy troue liefde duur vir altyd. want sy troue liefde duur vir altyd. want sy troue liefde duur vir altyd.

want sy troue liefde duur vir altyd. want sy troue liefde duur vir altyd. want sy troue liefde duur vir altyd.

want sy troue liefde duur vir altyd. 


\section{Psalm 136: 'n Liturgie as herinnering en herbelewenis van God se krag}

11 en Israel uit hulle midde uitgelei het,

12 met 'n magtige hand en 'n uitgestrekte arm,

13 aan Hom wat die Rietsee verdeel het, 14 en Israel daardeur gebring het,

15 maar Farao en sy leër in die Rietsee gewerp het,

16 aan Hom wat sy volk deur die woestyn gelei het,

17 wat groot konings verslaan het,

18 en magtige konings doodgemaak het,

19 Sihon, die koning van die Amoriete,

20 en Og, die koning van Basan,

21 en hulle land as 'n erfdeel gegee het,

22 'n erfporsie vir sy dienskneg Israel;

23 aan die Een wat ons in ons lae posisie onthou het, 24 en ons van ons teenstanders bevry het, 25 wat aan elke skepsel kos voorsien.

26 Bring dank aan die God van die hemel. want sy troue liefde duur vir altyd. want sy troue liefde duur vir altyd.

want sy troue liefde duur vir altyd. want sy troue liefde duur vir altyd. want sy troue liefde duur vir altyd.

want sy troue liefde duur vir altyd. want sy troue liefde duur vir altyd. want sy roué liefde duur vir altyd.

want sy troue liefde duur vir altyd. want sy troue liefde duur vir altyd. want sy troue liefde duur vir altyd. want sy troue liefde duur vir altyd.

want sy troue liefde duur vir altyd. want sy troue liefde duur vir altyd. want sy troue liefde duur vir altyd.

want sy troue liefde duur vir altyd.

\subsection{Struktuur}

\subsubsection{Inleiding}

Daar is wyd gedebatteer oor die stilistiese struktuur van Psalm $136 .{ }^{4}$ Hierdie bespreking sluit verskeie voorstelle in om die teks in kleiner eenhede te verdeel. My eie literêre analise dui aan dat die gedig in drie-vers strofes verdeel kan word, met die uitsondering van verse 16-22 en die afsluitende oproepe in vers 26 . Die strofes verbind onderling om groter of kleiner stansas te vorm, terwyl 'n imperatief-raamwerk (1-3; 26) die sentrale liggaam (4-25) van die psalm omarm.

Behalwe vir die gedurige voorkoms van die refrein "want sy troue liefde duur vir ewig" regdeur die teks, is die ander mees prominente kenmerkende verskynsels die herhaling van Leitwörte en Partisipia. Verskeie woorde en frases word herhaal ten einde kohesie te bewerkstellig, of om die teologiese betekenis van sommige sleutelkonsepte in die psalm te benadruk. Belangrike voorbeelde sluit die volgende in: I. הודו (bring dank aan, vv 1-3; 26); לעשה (2) לעכוד

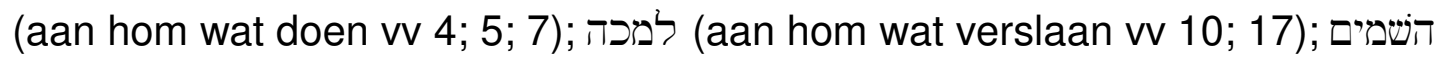

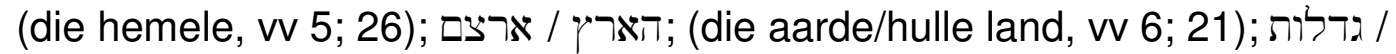
גדלים (groot, vv 4; 7; 17); שראל:. (Israel, vv 11; 14; 22);

\footnotetext{
${ }^{4}$ Allen (1983:231-232) gee 'n oorsig oor belangrike bydraes in die bespreking.
} 
15); מלכים / מלן (konings/koning, vv 17; 18; 19; 20); en נחלה (erfporsie, vv 21; 22).

Beide die literêre en die kultiese tradisies se teenwoordigheid kom in die teks na vore. 'n Tradisie-historiese analise dui duidelik aan hoedat kultiese en literêre motiewe met ander psalms gedeel word. Verder kom soortgelyke motiewe voor as dié wat by Deuteronomium of die deuteronomiste ${ }^{5}$ teenwoordig was, terwyl die inhoud van die Pentateug- ${ }^{6}$ en priesterlike tekste ${ }^{7}$ ook aan die teks se outeur(s) bekend was.

Mitologiese sinspelings ${ }^{8}$ funksioneer subtiel, hoewel sporadies, en meesal om by te dra tot die polemiese karakter wat soms in die teks na vore kom. Ooreenkomste ten opsigte van struktuur en inhoud ${ }^{9}$ tussen Psalms 135 en 136 is duidelik. Dit behoort egter individueel bepaal te word of 'n motief, 'n vers afhanklik is van tradisies buite die betrokke psalms. In die meeste gevalle is die moontlikheid van direkte afhanklikheid twyfelagtig, en die afhanklikheid van gemeenskaplike tradisies meer waarskynlik (Weiser 1979:547; Loretz 1979:313-314).

Psalm 136 bevat verskeie himniese beskrywings wat Jahwe se eindelose troue liefde beskryf חסדו). Hierdie beskrywende lof van Jahwe, wat in alle gevalle met sy die dankseggende lofprysing van Jahwe vir sy kwaliteite en dade in die skepping en geskiedenis. Behalwe vir die oproepe om dank te bring aan hierdie allerhoogste God in die inleidende (vv 1-3) en afsluitende (v 26) gedeeltes van die psalm, bestaan die sentrale dele uit motivering(s) vir hierdie oproepe (vv 4-22), asook uit 'n konkrete toepassing (vv 23-25) van God se verlossing in die huidige geloofsgemeenskap.

Die eerste stansa dien as motivering vir die oorspronklike oproep tot himniese danksegging, en verwys na God se universele handelinge, en spesifiek na sy dade gedurende die skepping (vv 4-9). In die daaropvolgende

\footnotetext{
${ }^{5}$ Vergelyk vers 2 met Deut 10:27; vers 11 met Deut 1:27; 4:20; 5:15; vers 12 met Deut 4:34; 5:15; 7:19; 9:29; 11:2; 26:8; 1 Kon 8:42; 2 Kon 17:36; vers 16 met Deut 8:15; 32:10; vers 19 met Deut 2:33; vers 22 met Deut 32:36; verse 17-18 met Jos 12, sien ook Keil \& Delitzsch (1973:329).

${ }^{6}$ Vergelyk vers 10 met Eks 11-12; vers 11 met Eks 7:5; 18:1; 20:1; vers 12 met Eks 6:1, 6; vers 13 met Eks 14:16-31 (veral 16-17 \& 21); vers 14 met Eks 14:22; vers 15 met Eks 14:27; verse 17-22 met Num 21:21-24, 33-35.

${ }^{7}$ Vergelyk verse 7-9 met Genesis 1:14-16.

${ }^{8}$ Vergelyk verse 2-3; 5-6; 13 and 15.

${ }^{9}$ Die struktuur van Ps 135 volg ook die patroon van Ps 136: 'n Inleiding en gevolgtrekking vorm 'n raamwerk wat bestaan uit oproepe vir die lofprysing van Jahwe (1-3; 19-21), terwyl die liggaam die redes vir hierdie lofprysing verskaf. Met betrekking tot die inhoud, vergelyk Ps 136:10 met 135:8; 136:15 met 135:9;136:17-22 met 135:10-12.
} 
stansa (vv 10-22) motiveer beskrywings van Jahwe se spesifieke betrokkendheid in die geskiedenis van Israel dieselfde oproepe, terwyl die laaste stansa (vv 23-25) beskryf hoe Jahwe die huidige gesalg gelowiges, die "ons", uit 'n soortgelyke lewensbedreigende situasie bevry het. 'n Heropname van God se universele werksaamhede kulmineer in die verwysing na sy voorsienende sorg vir alle skepsels. Uiteindelik kom daar 'n hernieude oproep om Jahwe as die God van die hemele te dank (26).

Om om te som, die buitengewone dade van Jahwe by die skepping en tydens die geskiedenis van Israel lewer voldoende motivering vir die aanbiddingsgemeenskap van Israel om Hom te eer en dankseggende lof te bring. Deur die kultiese herlewing en herinnering aan Jahwe se optrede in die verlede met ritueel, herhalende uitroepe of vertelling word Jahwe se goedheid opnuut beleef en lewend gemaak in die gemeenskap van Israel se gelowiges.

\subsubsection{Teksanalise}

\subsubsection{Inleiding: Oproep tot himniese danksegging (vv 1-3)}

In resonansie met die drieledige oproep tot eer aan Jahwe in Jesaja 6 begin Psalm 136 met 'n drieledige oproep tot lof. Met 'n tipiese liturgiese formule (Ridderbos 1950:15; Anderson 1972:894; Seybold 1996: 507), ${ }^{10}$ "Bring dank aan die HERE, want Hy is goed, want sy troue liefde duur vir altyd", word die Israelitiese aanbiddingsgemeenskap opgeroep om himniese dank aan Jahwe te bring. Selfs die motivering vir hierdie uitdaging, כי טוב (want Hy is goed), was waarskynlik 'n kultiese uitroep (Gerstenberger 2001:384). ${ }^{11}$ Daarna kon die liturgiese wisselwerking tussen 'n voorsanger en geloofsgemeenskap of tussen 'n (Levitiese) koor en die gemeente plaasvind. ${ }^{12}$ In antwoord op die oproep uitdaging van die roepende stemme, vorm die herhalende refrein 'n gallery van getuies om uiting te gee aan Israel se kollektiewe ervarings van Jahwe se חסד.

\footnotetext{
${ }^{10}$ Kyk ook 1 Kron 16:34; 2 Kron 5:13; 20:21; Ps 100:4-5; 105:1; 106:1; 107:1; 117:2; 118:1, 29; Esra 3:11; Jer 33:11.

${ }^{11}$ Kyk ook Ps 52:11; 54:8; 69:17; Nah 1:7.

${ }^{12}$ Vanweë die onseker identiteit van die liturgiese deelnemers, behoort die veelheid van moontlikhede in aanmerking geneem te word. Hetsy die gemeente as geheel, of al die verteenwoordigers (koor) kon gereageer het op die oproep van 'n priester of die Levitiese verteenwoordigers (koor) tydens die liturgie. Tyd en omstandighede kon die toneel en stemme laat varieer het. In Babiloniese tekste is die tweede deel van die vers gewoonlik deur 'n priesterlike koor gesing, sien König (1927:452).
} 
Psalm 136 reflekteer die tipiese struktuur van 'n himne. ${ }^{13}$ Drie imperatiewe van dieselfde werkwoord (ידה), wat telkens deur 'n datief voorsetsel ל (vir/aan) met partikel ${ }^{14}$ en 'n verdere beskrywing gevolg word, verbind verse 1-3 sintakties saam as ' $n$ strofiese eenheid. Jahwe is die objek van die gemeente se antwoord in verse 4-25, maar sy naam verskyn nie weer tot en met die finale himniese oproepe nie. Die voorsetsel I in kombinasie met die bepaalde werkwoorde in die res van die gedig $(4-7 ; 10 ; 13 ; 16-17)$, verbind die imperatiwiese oproepe sintakties met Jahwe as objek van die lofprysing. Verse 4-22 word oorheers deur hierdie imperatiewe. Beide die imperatiefvorme en goddelike titels in verse 1-3 en 26 plaas deur middel van ' $n$ inclusio die inhoud van die psalm binne 'n himniese raamwerk.

Die twee beskrywings "God van die gode" en "Heer van die here" (vv 23) verwys waarskynlik na die politeïstiese polemiek in die vroeëre ontwikkelingsfases van hierdie uitdrukkings. Teen hierdie politeïstiese agtergrond verkondig die titels die alleenmag van Jahwe as die Hoogste God. Aangesien verskeie aanduidings in die psalm 'n ná-eksiliese datum vir die finale komposisie daarvan suggereer, verleen die absolute monoteïstiese aard van die Jahwe-geloof gedurende hierdie tydperk van Israelitiese geskiedenis 'n superlatiewe funksie aan hierdie titels. Terwyl die uitdrukkings sinspeel op die mitologiese beeld van 'n antieke-Nabye-Oosterse panteon, kon hierdie titels deel uitgemaak het van die Jerusalemkultus, ten einde Jahwe as die ontbewisbare, onvergelyklike en alleenregerende God te beskryf. ${ }^{15}$ Sy mag en die terrein van sy heerskappy word spoedig in die psalm blootgelê.

\subsubsection{Jahwe, die God van die skepping}

In twee aparte strofiese eenhede (vv 4-6; 7-9) wat elk deur die himnies partisipiale frase לעשה (aan hom wat doen/maak) en die adjektief גדול (groot) ingelei word, word die uitsonderlike wonderdade van Jahwe gedurende die skepping gelys. Beide strofes is sintakties en stilisties verbind in ' $n$ drie-vers patroon. ' $n$ Beskrywende inleidende frase tot Jahwe se kreatiewe handelinge (vv 4 en 7) word gevolg deur ' $n$ voorstelling van twee teenoorgesteldes of pare - die hemele en aarde, son en maan, dag en nag. Dus is hierdie stansa (vv 4-9) as geheel 'n eulogie of lofprysing (Gerstenberger 2001:384) van die

\footnotetext{
${ }^{13}$ Spieckermann (2003:144) verkies die gedagte van 'n antifoniese himne.

${ }^{14}$ Hierdie partikel kan as 'n kousale merker (want) as emfatiese bevestiging geïnterpreteer word (ja/voorwaar).

${ }^{15}$ Sien ook Deut 10:17; Ps 50:1; 95:3; 96:4; 97:9; 135:5. Die Babiloniese god Marduk is ook vereer met die titel "Heer van here", (vgl Gunkel 1926:577).
} 
skeppende krag van Jahwe, terwyl die werkwoord עשה (om te maak) en partisipiale beskrywings verdere literêre samehang in die stansa bewerk.

Die "groot wonders" of tekens (פלאות) waarvoor Jahwe verantwoordelik is ( $v 4)$, beskryf beide sy kreatiewe en reddende aktiwiteite ${ }^{16}$ volgens die Ou-Testamentiese tradisies. Dit is verder ' $n$ Leitbegriff van die himne (Seybold 1996:507) en neig om 'n samevatting te wees van al die komende goddelike dade soos beskryf in verse 4-25. In verhouding tot die politeïstiese sinspelings in verse 2-3 druk die aanduiding dat Jahwe hierdie dade alleen (לבדו) sy unieke karakter in vergelyking met die ander (hemelse) kragte en gode uit. $\mathrm{Hy}$, alleen, het die hemele en aarde geskep, insluitende die hemelligame soos die son, maan en die sterre. 'n Polemiese atmosfeer is in die stansa speurbaar, soos wat die attribute van Jahwe teenoor die antieke-NabyeOosterse geloof in die mag van vergoddelikde hemelligame uitgebeeld word. Psalm 136 devalueer laasgenoemde as blote skepsels van die Allermagtige God, Jahwe, wat nie dieselfde krag as Hy het nie.

Die mitologiese wêreldbeeld van 'n drieverdieping-gebou met die hemele, die aarde en die water onder die aarde kom na vore in verse 5-6. 'n Ander skeppingsverhaal van die aarde kom egter in vers 6 voor, wat verskil van die priesterskrif se weergawe van Genesis 1:9. In eersgenoemde word die aarde uitgesprei oor die ondergrondse waters, ${ }^{18}$ terwyl laasgenoemde die verskyning van die droë grond beskryf as die gevolg van waters wat Jahwe onder die hemel versamel het. Sinspelings op die priesterlike narratief van Genesis 1:14-16 reflekteer ook die outeurs se onafhanklike gebruik en toepassing van ander literêre en kultiese tradisies in die teks. So is die uitdrukking "ligte" (אורים) in vers 7 byvoorbeeld 'n hapax legomenon in die Ou Testament, en verskil dit van die המארת in Genesis 1:16. Verder word die sterre in Psalm 136 mede-regeerders van die maan, terwyl dit in Genesis 1:16 die klein lig alleen is wat oor die nag heers. Nietemin word Jahwe se heerskappy, grootheid en krag oor tyd en ruimte benadruk in die beskrywing van sy skeppingshandelinge.

Kultiese formules weerklink duidelik in verse 5-6. In liturgiese en profetiese kontekste is die formule "Jahwe, skepper van hemel en aarde" waarskynlik as deel van 'n seënformule gebruik, of as 'n belydenis in die kultus om God se mag te vier (Habel 1972:333). ${ }^{19}$ Op 'n soortgelyke wyse is

\footnotetext{
${ }^{16}$ Kyk Eks 34:10; Jos 3:5; Job 5:9; 37:5, 14; 42:3; Ps 72:18; 78:4, 11; 86:10; 96:3; 98:1; 105:5; 106:7, 22; 107:8, 15, 21, 24, 31; 119:18; Dan 11:36; Miga 7:15.

${ }^{17}$ Kyk Ps 72:18; 86.10 en Jes. 2:11.

${ }^{18}$ Kyk Ps 24:2; Jes 42:5; 44:24.

${ }^{19}$ Gen 14:19; Ps 115:15; 121:2; 124:8, 134:3; 146:5, 6a.
} 
die beskrywing "aan hom wat die aarde uitgesprei het" in vers 6 afkomstig van 'n kulties-himniese tradisie waarin lofprysing aan Jahwe gebring is (Ludwig 1973:347-349). ${ }^{20}$ Uiteindelik dra die ondertone van beide verse ' $n$ himniese element om Jahwe se onvergelykbare skeppingskrag te beskryf.

In verse 4-9 onderskryf hierdie skeppende krag dus Jahwe se troue liefde en dien dit as die motivering vir die gelowiges se danksegging aan hom by wyse van die himne.

\subsubsection{Jahwe, die God van Israel se geskiedenis}

Verse 10-22 bestaan uit twee stansas (vv 10-15; 16-22), wat verder in vier strofiese eenhede ingedeel kan word (vv 10-12; 13-15; 16-18; 19-22). Elke strofe is 'n stilhouplek op die weg van Israel se heilsgeskiedenis, waar Jahwe se kragtige betrokkenheid in sy dienskneg se lewe beskrywe word: Israel se uittog uit Egipte (vv 10-12), die verlossing by die Rietsee (vv 13-15), Jahwe se leiding en beskerming in die woestyn (16-18), sowel as sy gawe van die groot konings se land as erfdeel aan Israel (19-22).

God se reddingsdade tydens die Egiptiese uittog en die intog in die Beloofde Land vorm die boustene van hierdie geskiedenis. Klem op hierdie twee tradisie-historiese temas te midde van die afwesigheid van die Sinaïtradisie sinspeel op die verloop van gebeure soos dit in die sogenaamde "klein historiese kredo" van Deuteronomium 26:5 en 6:20 beskryf word. Psalm 136 se verdere verwysings na die skepping (vv 4-9) en die woestyntog ( $v 16$ ) is kenmerkend van 'n eie styl, maar herinner tog ook aan ander tekste wat 'n himniese of belydende aard adem. ${ }^{21}$

Die verhouding tussen Psalms 135 en 136 word veral duidelik in hierdie twee stansas. ${ }^{22}$ Voorstelle dat beide psalms van dieselfde outeur afkomstig is (Van der Ploeg 1974:418), of dat Psalm 135 van Psalm 136 afhanklik is, is onoortuigend in die lig van die duidelike literêre en konteksgebasseerde verskille tussen die twee psalms. Die afhanklikheid van Psalm 136 van Psalm 135 is eerder moontlik, maar ook onseker. Dit is meer waarskynlik dat beide psalms onafhanklik ontwikkel het, terwyl beide moontlik gebasseer is op ' $n$ gesamentlike mondelinge of geskrewe tradisie. ${ }^{23}$

Die eerste strofe van hierdie stansa (vv 10-12) herroep die wonderdade van Jahwe tydens Israel se bevryding van Egiptiese slawerny. Hierdie

\footnotetext{
${ }^{20}$ Die formule kom slegs in Deutero-Jesaja (40:22; 45:12; 51:13) en in Ps 136 voor.

${ }^{21}$ Kyk Ps 78; 105; 135; Eks 15; Jos 24.

${ }^{22}$ Vergelyk Ps 136:10 met 135:8; 136:15 met 135:9; 136:17-18 met 135:10; 136:19-20 met 135:11; en 136:21-22 met 135:12.

${ }^{23}$ Kyk Loretz (1979:313-314) vir 'n opsomming van die verskille en sy soortgelyke gevolgtrekking.
} 
beskrywings herrinner aan die narratief in Eksodus 11-12. Soos by die aanvang in vorige strofes, word vers 10 ingelei deur die voorsetsel I en 'n partisipiale beskrywing. Verse 10 en 11 is nie slegs sintakties met die verbindingspartikel waw verbind nie, maar vanuit 'n Israelitiese perspektief word Jahwe se verlossingsdade eers met betrekking tot Egipte ( $v 10)$, en dan met betrekking tot Israel ( $v$ 11) beskryf: Hy het die vyand verslaan en Israel daarna uit nood en gevaar gelei. In deuteronomies-deuteronomistiese styl beskryf vers 12 die wyse waarop hierdie kragtige dade verrig is: met 'n sterk hand en 'n uitgestrekte arm - antropomofiese simbole wat Jahwe se mag en beskerming uitdruk.

In die tweede strofe van hierdie stansa (vv 13-15), word die verdeling van die Rietsee en Jahwe se oorwinning oor Farao en sy leëmag verkondig. Ingelei deur die voorsetsel I en 'n partisipiale werkwoord, vorm die eenheid 'n koherente geheel. Samehang word bewerk deur 'n inclusio met die begrip ים־סוף (Rietsee) in verse 13 en 15, terwyl die twee waw-partikels in verse 14 en 15 al drie verse sintakties saambind. Op 'n poëtiese of sinkroniese vlak word Israel se veilige reis deur die lewensbedreigende waters skilderagtig uitgebeeld met die twee verwysings na die Rietsee (vv 13,15) wat Israel se naam omring ( $v$ 14). Tradisie-histories sinspeel al drie verse op Eksodus 14, die Pentateug se vertelling van Israel se tog deur die Rietsee. ${ }^{24}$

Binne hierdie konteks verdien die uitdrukking גזר ים־סוך לגזרים (v 13) verdere melding. In vergelyking met tekste soos Genesis 15:17 en 1 Konings 3:25, waar die werkwoord גזר voorkom, kan afgelei word dat die werkwoord beteken "om in stukke te sny". Die interpretasie dat Jahwe die Rietsee verdeel het deur dit in stukke te sny het beide polemiese en teologiese implikasies. So 'n voorstelling sinspeel duidelik op die mitologiese Drachenkampf-stryd in Ugarit (Deissler 1964:529; Kraus 1978:1080), of op die god Marduk wat, volgens die Babiloniese Enuma Elisj epos, ${ }^{25}$ die liggaam van Tiamat in stukke gesny het. Onmiddelik is 'n polemiek tussen die magte van die Kanaanitiese en die Babiloniese gode aan die een kant, en Jahwe aan die ander kant, op die spel. By die outeur(s) van Psalm 136 bestaan daar geen twyfel dat Jahwe oor alle oppermag beskik nie. In Israel se primêre heilservaring by die Rietsee, oorskry sy mag alle ander chaosmagte, sowel as die mag van ander antieke-Nabye-Oosterse gode. Daarom verdien Jahwe van Israel se geloofsgemeenskap dankseggende lof vir sy seëvierende mag.

\footnotetext{
${ }^{24}$ Vergelyk 136:13 met Eks 14:16-31, veral vv 16 en 21; 136:14 met Eks 14:22; $136: 15$ met Eksodus 14:22.

${ }^{25}$ Kyk Hallo \& Younger (1997:398) vir die Enuma Elish epos op Tablet IV/135.
} 
In die eerste strofe van die tweede stansa, beeld verse 16-18 uit hoe God Israel in die woestyn en in die oorloë met die konings begelei het. Israel was in haar omswerwings deur die woestyn, soos by die Rietsee, aan gevaarlike bedreigende magte, naamlik die konings van die ander nasies blootgestel. Deur herhaling van die meervoudige naamwoord מלכים (konings), en die parallelle beskrywings van Jahwe se vernietigende handelinge, verbind verse 17-18 aan mekaar. Weereens is verse 16 en 17 verbind deur die himniese partikels met die voorsetsel ל en 'n partisipiale werkwoord.

Verse 19-22 fokus gedetaileerd op die oorlogsleiers en op die gevolge van die oorloë. Hierdie verse vertoon 'n sterk verbintenis met die voorafgaande strofe (vv 16-18), gegewe die herhaling van die naamwoord מלד (koning) in beide verse, en die tradisie-historiese verbintenis van hierdie verse met Psalm 135. Beide Sihon, koning van Gesbon, en Og, die koning van Basan, is eksemplariese prototipes van vyande in Israel se geskiedenis wat as oorwonne en legendariese teënstanders ${ }^{26}$ dien. Hulle mag selfs dien as legendariese helde of mitologiese figure met bomenslike kragte, ${ }^{27}$ maar Jahwe se oorwinning oor hulle in die Trans-Jordaan gebied illustreer sy mag oor hierdie lewensbedreigende historiese magte. Die oorwinning bevestig verder sy verhewe, goddelike heerskappy in opeenvolgende, hopelose en lewensbedreigende situasies dwarsdeur sy volk se bestaan.

Deur die outeur(s) se aanwending van stilistiese verskynsels soos anadiplose en die herhaling van die naamwoord נִחלה (erfdeel) word verse 21 en 22 verbind om te fokus op die land wat Jahwe as 'n erfdeel aan Israel gegee het. Betekenisvol is die psalmis se gebruik van die term הארץ in die teks. Die ארץ (aarde) wat God met sy skeppende kragte gevestig het ( $v 6)$, is deur die krygergod Jahwe van die konings ( $v 21$ ) weggeneem met sy mag. Dit het Hy gedoen om die ארצם (hulle land) aan Israel te gee. Israel het die land van Jahwe ontvang, maar dit is juis in hulle verhouding met Hom dat Israel se rol in vers 22 as עבדו (sy dienaar) in hierdie land beskryf word. ${ }^{28}$ Dit is hier waar hulle hul diens aan Jahwe, die Skepper en Gewer van die land, ${ }^{29}$ moet uitoefen. Binne die konteks van die psalm impliseer hierdie diens 'n houding van lof, omdat Jahwe Israel se Egiptiese slawerny in 'n situasie verander het

\footnotetext{
${ }^{26}$ Gerstenberger (2001:387) beeld hierdie figure uit as "examples for the multitude of other local kings" (Deut 1:4; 2:26-3.11; 29:6; 31:4; Rigt 11:19-22).

${ }^{27}$ Gerstenberger (2001:387) verwys ook na Jos 13:12 hiervoor.

${ }^{28}$ Seybold (1996:508) sien vers 22 as die hoogtepunt van die himne.

${ }^{29}$ Vergelyk Israel as "dienaar" in Jes $41: 8$; 44:1, ens.
} 
waarin hulle hom as dienaars kan dien. Daarom roep die liturgie die gelowiges op om aan Jahwe dank en lof te bring.

\subsubsection{Eietydse toepassing}

In die laaste strofiese eenheid van die psalm (vv 23-25) vind die leser skielik 'n verandering in taal en styl. Die vorige derdepersoon beskrywings maak nou plek vir die eerstepersoon meervoud (ons) beskrywing. 'n Relatiewe beskrywing, ingelei deur vers 23, asook die afwesigheid van die voorsetsel as inleiding tot die partisipiale werkwoord נתן (v 25) kenmerk hierdie 3 verse, in onderskeid van voorafgaande strofes. Die sintaktiese verbintenis tussen verse 23 en 24 is daarom duidelik vanweë die eerstepersoon meervoud verwysings.

Beide verse reflekteer 'n meer kontemporêre ervaring vir gelowiges uit 'n latere periode as die wat uit Israel se geskiedenis beskryf is - waarskynlik 'n laat ná-eksiliese ${ }^{30}$ tydperk. Indien hierdie verse getuig van 'n latere byvoeging tot die teks, dien hulle waarskynlik as latere, dit wil sê, as huidige gelowiges se reddingservaring van dieselfde God van die skepping en die geskiedenis. Hierdie keer is dit 'n toepassing van die krag van dieselfde God, net op 'n latere stadium in die geskiedenis. Indien hierdie verse dus deel was van die oorspronklike psalm, getuig hulle van 'n later datum vir die teks as geheel.

Die lae of nederige posisie ( $v$ 23) waarin die huidige gemeenskap haarself bevind dui op 'n lewensbedreigende situasie, waar die "ons" deur teëstanders bedreig word ${ }^{31}$. Duidelike woorspel tussen מִצרינו (ons teëstanders) van 24 in verhouding tot מצרים (Egipte) in vers 10, suggereer dat die huidige gevaar soortgelyk is aan die lyding van die slawerny in Egipte en die onderwerping aan die farao. Die primêre gevaar van Israel se ervaring in Egipte word herhaal, en die vyande word weer verslaan. Hierdie oorwinning verseker dat Jahwe se reddingsdade 'n voortgaande en durende karakter vertoon. Jahwe het weer eens sy volk uit hul Egiptiese "slawerny" situasie bevry. Die chiasme tussen verse 23 en 24 onderstreep nie slegs die veranderende lot en omstandighede van die huidige geslag gelowiges nie,

\footnotetext{
${ }^{30}$ Bewyse vir so 'n laat datering lê waarskynlik in die laat relatiewe partikel $ש$ ( $(v 23)$, die term שפל (v 23), wat slegs in die laat teks van Pred. 10:6 bekend is asook die werkwoord (v 24), wat ' $n$ algemeen bekende Aramese term was, vgl Delitzsch (1973:331) en Allen (1983:231).

${ }^{31}$ Verskillende voorstelle word gemaak om hierdie "lae posisie" van die "ons" te plaas. Moontlikhede sluit in: gebeure van die Rigterstydperk; gebeure tydens die regering van Dawid; die Babiloniese ballingskap en terugkeer (Klaagl 5:8); of gebeure rondom die besetting van die land Kanaän tot die Persiese tydperk.
} 
maar ook Jahwe se gedagtenis aan sy volk het in sy reddingsdade 'n parallelle beskrywing vind.

Vers 25 hervat die himniese beskrywing van die universele rol van Jahwe as die Een wat omgee en aan alle skepsels voorsien. Na sy spesifieke betrokkenheid by die Israelitiese geskiedenis ( $v$ v 10-22), voorsien Jahwe nou aan alle vlees, ${ }^{32}$ 'n aanduiding van sy besorgdheid oor die skepping in geheel, en nie slegs oor die volk Israel nie. Jahwe is nie slegs die God van Israel nie, maar Hy is die universele God van Alles.

\subsubsection{Finale oproep om dank te bring}

Die laaste vers van Psalm 136 herhaal die oproepe van verse 1-25 om dank aan Jahwe te betuig en is deel van die imperatiwiese raamwerk van die teks. Die goddelike eienskap "God van die hemele", is 'n hapax legomenon in die Psalms en het sy oorsprong waarskynlik uit 'n relatiewe laat stadium, die Persiese tydperk. ${ }^{33}$ So 'n laat datum ondersteun die aanname dat die vers moontlik met die voorafgaande strofe verbind en 'n latere byvoeging tot die teks was. Deur van hierdie epiteton gebruik te maak, word die verhewe aard en goddelikheid van Jahwe emfaties beklemtoon.

\subsection{Kultiese Sitz im Leben}

Die teksanalise maak dit duidelik dat die Sitz im Leben van Psalm 136 by die kultus tuishoort. Definitiewe spore van liturgiese elemente in Israelitiese aanbidding is herkenbaar. Kultiese formules soos die oproep tot lofprysing ( $v \mathrm{v}$ 1-3; 26), die liturgiese uitroepe ( $v 1$ ), 'n liturgiese responsorium (vv 1-26), die verandering vanaf oproep na reaksie (vv 1-26) en die wisseling tussen sprekers van twee groepe, hetsy tussen 'n voorsanger en die gemeente of tussen twee kore, is alles aanduidings van die psalm se kultiese funksie (Mowinckel 1962:83; Westermann 1989:271). Veral die sogenaamde Wechsellieder (liedere gekenmerk deur afwisseling) met die Kehrvers (antwoord) was kenmerkend van die Israelitiese liturgie (Gunkel \& Begrich 1933:404).

Alhoewel die wisseling van stemme in die Israelitiese kultus 'n kunstige en doelbewuste metode van uitdrukking in 'n psalm sou wees, behels die wisseling en deelname van die gemeente meer as blote poëtiese strategie of 'n digter se uitdrukking van estetiese waarde. In die liturgie druk die deelname van die gemeentelede 'n verhouding van verbondenheid aan die goddelikheid

\footnotetext{
${ }^{32}$ Kyk Ps 104:27-28; 145:15; 146:7.

${ }^{33}$ Die titel "God van die hemele" kom voor in Esra $1: 2 ; 5: 11 ; 6: 9 ; 7.12$; Neh 1:4; 2:4; 2 Kron 36:23; Jona 1:9; Dan 2:18, wat almal sinspeel op die Persiese periode.
} 
uit. Dit is 'n manier van Israel se gemeenskap en kommunikasie met Jahwe, die Gewer van lewe. In die lewendige opvoering van die liturgie se inhoud, herbeleef die gelowige die goddelike, terwyl die hoop en geloof in Jahwe, die God van die skepping en die geskiedenis, daardeur opflikker.

Die presiese kultiese aanbiddings- of feestelike geleenthede vir die uitvoering van Psalm 136 is steeds meerduidig. Verskeie voorstelle dui op moontlikhede waartydens hierdie liturgie kon afspeel. Dit sluit die volgende in:

- Die Hallel is tradisioneel geassosieer met die Joodse Paasfees (Anderson 1972:893; Kraus 1978:1079), vanweë die teks se herdenking van die eksodusgebeure. Hierdie gebeure sluit die dood van die eersgebore Egiptiese seuns ( $v 10)$, die redding en beskerming van Israel (vv 11-12), die verdeling van die Rietsee ( $v 13$ ) en die oorwinning oor farao en sy leërmag (vv 14-15) in. Alhoewel die eksodusgebeure en Jahwe se heilsdade 'n onontbeerlike rol in die psalm speel, mag dit problematies wees om hierdie liturgiese viering van Jahwe se krag of skepping en heil aan die kultiese viering van die Paasfees alleen te koppel. Dit was verseker nie die enigste plek waar hierdie liturgie 'n rol gespeel het nie, maar verseker 'n baie belangrike Sitz im Leben in terme van die kultiese tradisie, om Jahwe se verhewe goddelike krag, en sy oorwinning oor ander lewensbedreigende gevare te vier.

- 'n Ander voorstel (Oesterley 1939:543) is die Nuwejaarsfees in die herfs. Met die begin van die Nuwejaar is Jahwe se dade in die skepping en in Israel se geskiedenis herdenk. Sou gevaarlike situasies gedurende die komende jaar opduik, dien sy krag en mag as 'n bron van hoop en vertroue. Ná die ballingskap is hierdie fees waarskynlik deur die Israeliete in die lente en in die herfs gevier.

- Die Loofhuttefees bied nog 'n moontlikheid. Volgens 2 Kronieke 7:3 en 6 is die opsê van die formule "want hy is goed, want sy liefde duur vir altyd" begelei deur kultiese gebare soos neerbuiging. ${ }^{34}$ Saam met elemente soos God se leiding, beskerming en voorsienigheid (aspekte wat in die teks voorkom), kon die herbelewing van Psalm 136 'n gepaste Sitz gedurende in hierdie fees vind.

Sommige geleerdes (Schmidt 1934:240; Weiser 1962:793) is op grond van die noue verwantskap met Psalm 135 asook die klimaktiese klem op vers 25 (hy wat voedsel aan elke skepsel voorsien) oortuig dat hierdie psalm tot 'n

${ }^{34}$ Kyk ook Ps 95:2; 99:5. 
liturgie van die oesfees in die herfs behoort. Dit bly egter debatteerbaar om aan vers 25 alleen spesiale klem te verleen veral as die struktuur van die psalm nie daaop dui nie. Aspekte van skepping en heilsgeskiedenis soos die uittog of Jahwe se gawe van die land verdien gelyke belangrikheid in die interpretasie van die psalm en sy struktuur.

Die karakter van die psalm laat die moontlikheid dat die liturgie op die oggend van die Sabbat gebruik sou kon word (Deissler 1964:529). As 'n himne met 'n dankkarakter is dit heel moontlik.

Ten spyte van al hierdie moontlikhede is daar geen gewongenheid om die teks aan een enkele kultiese Sitz im Leben te verbind nie. Om deur middel van lofprysing dank aan Jahwe te bring, veral waar sy karakter en dade ter sprake is, antisipeer verskeie kultiese geleenthede waartydens Hy deur hierdie litanie-gestruktureerde liturgie vereer kon word. Hierdie lewegewende opvoering en herbelewenis van Jahwe se dade van skepping en redding in die kultus behoort op geen manier tot een enkele geleentheid beperk te word nie. Al die verskillende bogenoemde voorstelle dien as bevestiging hiervan.

\section{$2.4 \quad$ Moontlike datering}

Die datering van ' $n$ psalm as geheel is altyd problematies. Psalm 136 is geen uitsondering nie. Selfs as dele van 'n psalm op ' $n$ vroeëre of ' $n$ latere datering in Israel se geskiedenis dui, is dit nie noodsaaklik om die hele psalm dienooreenkomstig te dateer nie. Die mondelinge tradisie of stelselmatige groei van die geskrewe teks maak dit moeilik om 'n datering te bepaal.

Tog is daar verskeie aanduidings in Psalm 136 vir 'n ná-eksiliese datum. Alhoewel ouer kultiese en literêre tradisies (vv 5-6) in die psalm hoorbaar is, kon die finale teks teen die einde van die vyfde of die begin van die vierdie eeu $v C$ neerslag gevind het. Die teks se sinspelings op die Pentateug, veral op die priesterskrif en die Eksodustradisie, is duidelik. Die kontemporêre herbelewenis van die primêre Israelitiese heilservaring (vv 2324) vra vir 'n latere ná-eksiliese datering van die psalm. Selfs die epiteton in vers 26 sinspeel op beskrywings wat aan die Persiese periode behoort. Vanweë hierdie redes, en met die bewustheid dat die psalm as geheel nie op 'n homogene wyse hanteer behoort te word nie, mag die einde van die vyfde of die begin van die vierdie eeu $\mathrm{vC}$ as moontlike datum vir die finale teks van Psalm 136 aanvaar word.

\section{SLOTOPMERKINGS}

Psalm 136 is 'n litanie waarin elemente van die dankseggingshimne uitdrukking gee aan die viering van die karakter en dade van Jahwe. Wanneer hierdie gedig vertaal en voorgedra word in 'n lewendige situasie funksioneer 


\section{Psalm 136: 'n Liturgie as herinnering en herbelewenis van God se krag}

dit as 'n liturgie in die kultus. Dit is hier waar responsiewe stem(me) gedurig antwoord op die oproepe om aan Jahwe lof te bring en sy karakter en wonderlike dade te beskryf. As 'n basiese houding van die Ou-Testamentiese teologie se verstaan van die mens se lewensdoel, vorm die lofprysing van God die kern in die verhouding tussen Jahwe en Israel, of tussen God en mens (Janowski 2003:126-127).

'n Opeenvolging van God se skeppings- en reddingservarings in die liturgie benadruk die voortgesette en durende karakter van sy חסד (troue liefde). Op polemiese wyse word Jahwe in die psalm uitgebeeld as die "God van die gode", wat onvergelyklike krag in sy skepping en in die geskiedenis van sy volk openbaar het. Sy handelinge in skepping en geskiedenis beklemtoon dat Hy die enigste verhewe God is wat sy volk uit gevaarlike en lewensbedreigende situasies gered het.

Vir Israel het hierdie bevryding nie as 'n blote feit van die verlede bly bestaan nie, maar hulle het God se krag weer en weer in opeenvolgende omstandighede van hopeloosheid ervaar. Selfs 'n kontemporêre toepassing van die huidige gemeente ( $v$ 23-24) bevestig dat Jahwe hulle huidige "Egipte-ervaring" op sy hoof gekeer het. Israel het by herhaling die primêre heilsdaad van Jahwe, wat Hy by die Rietsee uitgevoer het, ervaar. In die gekonseptualiseerde woorde van die psalm self (vv 23-24), was dit deur sy herinnering aan die "ons" dat Hy "ons" uit "ons lae posisie" gered het.

God se herinnering aan Israel roep na die herinnering wat sy volk aan Hom moet hê, naamlik, as die dienaar Israel. Omdat Israel Jahwe se liefde in die skepping en in geskiedenis ervaar het, is hulle aan hom spesiale diens verskuldig. Hierdie diens kan op verskeie maniere en in verskeie tradisies lewend bly en na vore kom deur herhalende en himniese danksegging. Al die herinnerings aan God hou verband met die חסד-ervarings waarvoor alle gelowiges aan God dankbaarheid behoort te toon.

'n Hedendaagse herïnterpretasie van die psalm en sy basiese kultiese verbondenheid roep na verskeie kreatiewe maniere waarop God in die liturgie geprys kan word, en waarop sy wonderlike dade in skepping en geskiedenis lewend gehou moet word. Hierdie dade, wat vir die Christen-gemeente in en deur die lewe van Jesus Christus bevestig word, behoort op kreatiewe wyse by die verskeie elemente van aanbidding ter sprake kom. Wanneer dit gebeur sal die Jahwe-gelowiges nie alleen hul dankbaarheid uitdruk as 'n gevolg van sy wat hulle durend ervaar nie, maar hulle sal die geloof in die onvergelyklike "God van die gode", daarmee lewend hou. 


\section{Literatuurverwysings}

Allen, L C 1983. Psalms 101-150. Waco, TX: Word. (Word Biblical Commentary 21.) Anderson, A A 1972. The Book of Psalms Vol II. Grand Rapids, Ml: Eerdmans. (The New Century Bible Commentary.)

Baethgen, D F 1904. Die Psalmen übersetzt und erklärt. Göttingen: Vandenhoeck und Ruprecht.

Bazak, J 1985. 'The geometric-figurative structure of Psalm CXXXVI,' Vetus Testamentum 35, 129-138.

Burden, J J 1991. Psalms 120-150. Kaapstad: NG Kerk Uitgewers.

Crüsemann, F 1969. Studien zur Formgeschichte von Hymnus und Danklied. Neukirchen-Vluyn: Neukirchener Verlag. (WMANT 32.)

Deissler, A 1964. Die Psalmen. Düsseldorf: Patmos Verlag.

De Liagre Böhl, F M Th \& Gemser, B 1968. De Psalmen. Nijkerk: Callenbach. (Tekst en Uitleg.)

Duhm, D B 1922. Die Psalmen. Tübingen: Mohr Siebeck. (Kurzer Handkommentar zum Alten Testament. Bd XIV.)

Gerstenberger, E S 2001. Psalms Part 2 and Lamentations. Grand Rapids, MI: Eerdmans. (The Forms of the Old Testament Literature. Volume XV).

Gunkel, H 1926. Die Psalmen übersetzt und erklärt. Göttingen: Vandenhoeck \& Ruprecht. (Göttinger Handkommentar zum Alten Testament.)

Gunkel, H \& Begrich, J 1933. Einleitung in die Psalmen: Die Gattungen der religiösen Lyrik Israels. Göttingen: Vandenhoeck \& Ruprecht.

Habel, N C 1972. "Yahweh, Maker of heaven and earth': A study in tradition criticism," JBL 91, 321-337.

Hallo, W W \& Younger, K L (eds) 1997. The Context of Scripture: Canonical compositions from the biblical world, vol 1. Leiden: Brill.

Janowski, B 2003.'Dankbarkeit: Ein antropologischer Grundbegriff im Spiegel der Toda-Psalmen,' in E Zenger (Hrsg), Ritual und Poesie, 91-136. Freiburg: Herder.

Keil, C F \& Delitzsch, F 1973. Psalms. Grand Rapids, MI: Eerdmans. (Commentary on the Old Testament in ten volumes, Vol V).

Kirkpatrick, A F 1903. The Book of Psalms. Cambridge: University Press. (The Cambridge Bible for Schools and Colleges.)

Kittel, R 1922. Die Psalmen. Erlangen: Scholl. (Kommentar zum Alten Testament. Bd. XIII.)

König, E 1927. Die Psalmen. Gütersloh: Bertelsmann Verlag.

Kraus, H J 1978. Psalmen. Neukirchen-Vluyn: Neukirchener Verlag. (BKAT XV/2; Teilband 2.)

Loretz, O 1979. Die Psalmen, II. Neukirchen-Vluyn: Neukirchener Verlag. (Beitrag der Ugarit-Texte zum Verständnis von Kolometrie und Textologie der Psalmen. Alter Orient und Altes Testament. Veröffentlichungen zur Kultur und Geschichte des Alten Orients und des Alten Testaments.)

Ludwig, T M 1973. The traditions of establishing the earth in Deutero-Isaiah. JBL 92, 345-357.

Miller, P D 1995. Between text and sermon: Psalm 136:1-9, 23-26, Interpretation 49, 390-393.

Mowinckel, S 1962. The Psalms in Israel's worship, Vol II. Oxford: Blackwell. 
Psalm 136: 'n Liturgie as herinnering en herbelewenis van God se krag

Obermann, J 1936. An antiphonal psalm from Ras Shamra. JBL 55, 21-44.

Oesterley, W O E 1939. The Psalms. New York: Macmillan.

Ridderbos, N H 1950. Psalmen en Cultus. Kampen: Kok.

Schedl, C 1986. Die alphabetisch-arithmetische Struktur von Psalm CXXXVI. VT 36, 489-494.

Schmidt, H 1934. Die Psalmen. Tübingen: Mohr Siebeck. (Handbuch zum Alten Testament $\mathrm{l} / 15$.)

Seybold, K 1996. Die Psalmen. Tübingen: Mohr Siebeck. (Handbuch zum Alten Testament I/15.)

Spieckermann, H 2003. Hymnen im Psalter: Ihre Funktion und ihre Verfasser, in E Zenger (Hrsg), Ritual und Poesie, 137-162. Freiburg: Herder.

Stoebe, H J 1984. חסד - Hæsæd Güte, in Jenni, E \& Westermann, C (Hrsg), THAT (Bd I), 600-621. München: Kaiser Verlag.

Van der Ploeg, J P M 1974. Psalmen, Deel II (Psalm 76-150). Roermond: Romen \& Zonen.

Weiser, A 1979. Die Psalmen. Göttingen: Vandenhoeck \& Ruprecht. (Das Alte Testament Deutsch. Teilband 14.)

Westermann, C 1977. Lob und Klage in den Psalmen. Göttingen: Vandenhoeck \& Ruprecht.

Westermann, C 1989. The living Psalms, tr by J R Porter. Edinburgh: T \& T Clark.

Zenger, E (Hrsg) Ritual und Poesie: Formen und Orte religiöser Dichtung im Alten Orient, im Judentum und im Christentum. Freiburg: Herder. 